\title{
Evaluation of the enzymatic activity of selected bacterial strains
}

\author{
Sławomir Wierzba, Adam Latała \\ Opole University, Chair of Biotechnology and Molecular Biology, ul. Kominka 4, 45-032 Opole, Poland, \\ tel. +48 7740160 50; e-mail: kbsie@uni.opole.pl
}

\begin{abstract}
In these studies we attempted to evaluate the lipolytic, proteolytic and cellulolytic activity of bacterial strains isolated from water and the bottom sediments of Turawa Lake. The following bacterial genera prevailed among the isolated strains: Bacillus, Pseudomonas, Enterobacter, Cellulomonas and Cytophaga. The lipolytic activity was determined using a titrimetric method, the proteolytic activity - using a modified Anson method, and the cellulolytic activity - on the basis of mass decrement of a cellulose disk after 14 days of bacterial culture. The cultures were maintained at $28^{\circ} \mathrm{C}, \mathrm{pH} 7.0$ with the following substrates: olive oil, albumin and cellulose disk. Among the analysed microorganisms, Bacillus and Pseudomonas strains showed the highest lipolytic and proteolytic activity. In the cellulolytic assay Cytophaga bacteria showed about twofold higher activity than that of Celulomonas.
\end{abstract}

Keywords: bottom sediment, bacteria, lipolytic, proteolytic and cellulolytic activity.

Presented at VII Conference Wasteless Technologies and Waste Management in Chemical Industry and Agriculture, Międzyzdroje, 12 - 15 June, 2007.

\section{INTRODUCTION}

Microorganisms play an important role in changes occurring in nature and are often used in technological processes. Production of enzymatic preparations using bacteria, fungi or actinomycetes is one of the most important branches of biotechnology. Hydrolytic enzymes comprise almost $80 \%$ of the total production of enzymatic preparations ${ }^{1}$. Hydrolysis processes are widely applied in food industry, pharmaceutical industry and medicine, agriculture, and environment protection e.g. in the biodegradation of waste and sewage containing macromolecular compounds. The hydrolytic decomposition of organic matter by microorganisms in water ecosystems is possible owing to the activity of specific enzymes secreted outside the cells. Microorganisms bring about the mineralisation of organic compounds of phosphorus and nitrogen, in consequence increasing the availability of biogens for phytoplankton. Moreover, they are able to perform biodegradation in respect of particularly resistant humus substances, cellulose and chitin ${ }^{2}$. Most frequently, the sources of such compounds are the remains of dead plants and animals, and pollutants reaching lakes through the surface and ground water. The rate and efficiency of the changes of biochemical organic compounds in water environment depends, among other things, on the quantitative and qualitative content of microflora and its enzymatic activity. The purpose of the study conducted was to assess the lipolytic, proteolytic and cellulolytic activity of the selected bacterial strains isolated from the water and the bottom sediments of Turawa Lake.

\section{MATERIALS AND METHODS}

Turawa Lake comprises a complex of lakes including a large reservoir of $22 \mathrm{~km}^{2}$ in area and three small ones, located ca. $20 \mathrm{~km}$ north west from Opole. Similarly, as other shallow lowland buffer reservoirs, Turawa Lake is characterised by an advanced process of eutrophication. The tested material was sampled from three spots located in the north-western part of the lake. The water was sam- pled in May and June from the depth of $0.5 \mathrm{~m}$, directly to sterile glass containers. The bottom sediments were sampled at the same time from the depth of $5-6 \mathrm{~m}$ using a bottom bucket. The lipolytic and proteolytic bacteria were isolated on a mineral nutrient medium ${ }^{3-4}$. The cellulolytic bacteria were isolated on the Waksman medium $^{5-6}$ and then in a liquid medium of the following composition: $\mathrm{KNO}_{3}-2.5 \mathrm{~g} / \mathrm{dm}^{3}, \mathrm{KH}_{2} \mathrm{PO}_{4}-1.0 \mathrm{~g} / \mathrm{dm}^{3}$, $\mathrm{MgSO}_{4} \times 7 \mathrm{H}_{2} \mathrm{O}-0.3 \mathrm{~g} / \mathrm{dm}^{3}, \mathrm{CaCl}_{2}-0.1 \mathrm{~g} / \mathrm{dm}^{3}, \mathrm{NaCl}-$ $0.1 \mathrm{FeCl}_{3}-0.01 \mathrm{~g} / \mathrm{dm}^{3}$, potato starch $-20.0 \mathrm{~g} / \mathrm{dm}^{3}$, cellulose disks, $\mathrm{pH}$ 7.2. The isolated strains were kept on the agar substrate at $4^{\circ} \mathrm{C}$. For further testing the strains were grown on the enriched bouillon and the nutrient agar under aerobic conditions, at $28^{\circ} \mathrm{C}$. The total number of the bacteria was determined using the cultureplate method based on PN-75/C-04615 . The quality tests included a macroscopic, microscopic and biochemical analysis using a microanalyser mini $\mathrm{API}^{8}$. In the isolated and identified strains at a density of $10^{9} \mathrm{CFU} / \mathrm{ml}$, the enzymatic activity was evaluated. The lipolytic activity was determined by the titrimetric method, using $40 \%$ emulsion of olive oil as a substrate supplemented with Tween ${ }^{\mathbf{9}} \mathbf{1 0 - \mathbf { 1 1 }}$. The lipase activity results in fat decomposition into glycerol and fatty acids that were quantitatively determined in the postculture liquid of the strain tested using titration with $\mathrm{NaOH}$. The proteolytic activity was determined by a modified Anson method ${ }^{\mathbf{1 0}-11}$, using a 2\% albumin solution as the substrate. Albumin decomposed into the products soluble in trichloroacetic acid (TCL) and the content of tyrosine and tryptophan was determined spectrophotometrically using a Folin reagent. The cellulolytic activity was evaluated by analysing the mass decrement of a 250 mg cellulose disk in a 14-day culture of the tested strain on the Winogradski nutrient medium ${ }^{\mathbf{1 2}}$ under aerobic conditions.

\section{RESULTS AND DISCUSSION}

Evaluation of enzymatic activity of the isolated lipolytic and proteolytic strains is shown in Table 1. The bacteria produce the lipolytic enzymes both attached to a cell 
Table 1. Enzymatic activity of the isolated bacterial strains from Turawa Lake

\begin{tabular}{|l|r|r|}
\hline \multirow{2}{*}{\multicolumn{1}{|c|}{ The name of the strain }} & \multicolumn{2}{|c|}{ Enzymatic activity } \\
\cline { 2 - 3 } & $\begin{array}{c}\text { proteolytic } \\
{[\mu \mathrm{UA}]^{1}}\end{array}$ & $\begin{array}{c}\text { lipolytic } \\
{[\mathrm{UA}]^{2}}\end{array}$ \\
\hline Serratia marcescens & 1.00 & 11.00 \\
\hline Pseudomonas putida U23 & 8.22 & 12.00 \\
\hline Pseudomonas putida U22 & 11.28 & 8.50 \\
\hline Pseudomonas fluorescens U25 & 22.62 & 13.00 \\
\hline Pseudomonas fluorescens U19 & 28.95 & 18.00 \\
\hline Pantoea sp. & 2.14 & 10.00 \\
\hline Micrococcus U219 & 2.45 & 3.50 \\
\hline Ewingella americana & 7.32 & 6.00 \\
\hline Enterobacter sakazakii & 1.96 & 12.00 \\
\hline Enterobacter aerogenes & 1.00 & 12.50 \\
\hline Bacillus U18 & 14.29 & 3.50 \\
\hline Bacillus U15 & 16.96 & 3.00 \\
\hline Bacillus U14 & 6.79 & 12.25 \\
\hline Bacillus U13 & 2.14 & 8.00 \\
\hline Bacillus U12 & 31.40 & 2.00 \\
\hline Bacillus U11 & 29.16 & 3.00 \\
\hline Aeromonas caviae & 8.15 & 6.50 \\
\hline Acinetobacter Iwoffii & 29.45 & 12.35 \\
\hline
\end{tabular}

${ }^{1} \mu \mathrm{UA}$ - unit of activity corresponds to such a quantity of enzyme in $1 \mathrm{ml}$ of the tested material that hydrolyses albumin at such a rate that the quantity of the hydrolysis product, soluble in TCL, formed in 1 minute, provides absorbance corresponding to 1 millimole of tyrosine after reacting with a phenol reagent.

${ }^{2} U A$ - unit of activity expresses the quantity of mmoles of fatty acids formed during $1 \mathrm{~h}$ in $1 \mathrm{ml}$ of the post-culture liquid of a given strain.

and secreted to a medium ${ }^{10-13}$. The enzyme secretion enables to specify the activity of acylglycerol hydrolases in the postculture liquid in the presence of fatty substrate inducing their synthesis ${ }^{11-14}$. On the basis of the obtained results, the highest ability for the lipase synthesis was determined for Pseudomonas fluorescens U19 strain. The enzyme activity reached 18.00 units (UA). The activity lower by almost $28 \%$ was observed for Pseudomonas fluorescens U25 strain (13.00 UA). A similar lipase synthesis also characterised the following bacteria: Enterobacter aerogenes (12.50 UA), Acinetobacter lwoffi (12.35 UA), Bacillus U14 (12.25 UA), Enterobacter sakazakii (12.00 UA), Serratia marcescens (11.00 UA) and Pantoea sp. (10.00 UA). These activities were 30.6 $44.5 \%$ lower as compared with the most active strain.

Other strains showed the lipolytic activity lower by over $50 \%$ (Table 1, Fig. 1). High synthesis ability of acyloglycerol hydrolases by oxygen bacillus of Bacillus genus, e.g.: Bacillus subtilis, Bacillus pumilus, Bacillus coagulans, and bacillus of Pseudomonas genus, in particular: Pseudomonas fragi, Pseu-domonas fluorescens, Pseudomonas putida is confirmed by the studies of many authors ${ }^{\mathbf{1 4}-18}$. When testing the enzymatic activity of the microflora isolated from fatty waste, Latała and Wierzba ${ }^{4}$ also observed high lipolytic activity of Serratia and Acinetobacter strains and relatively low activity in the case of the Micrococcus strain. When testing the enzymatic activity of Bacillus subtillis, Trzmiel ${ }^{11}$ observed a substantially higher ability of the lipase synthesis by this strain and the results obtained were within the range of ${ }^{20-42}$ units of activity, depending on the temperature and $\mathrm{pH}$ of the culture.

Biosynthesis of acyloglycerol hydrolases depends on many external factors such as the type and the concentration of the substrate, enzyme activator, $\mathrm{pH}$ of the culture,

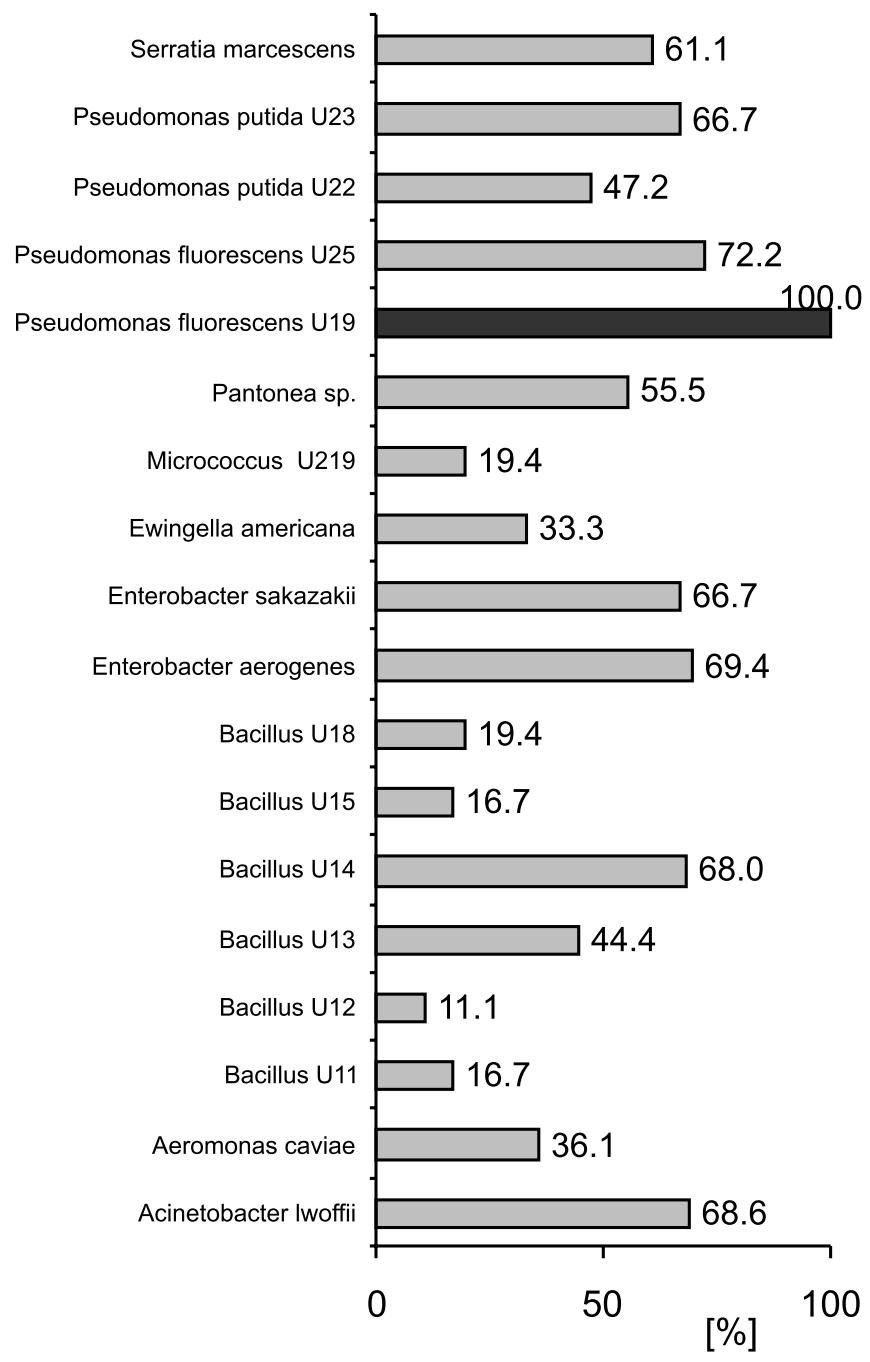

Figure 1. The percentage of the lipolytic activity of Turawa Lake bacteria in relation to the most active strain

the temperature, and the presence of easily available sources of carbon ${ }^{14}$. The inductors of the lipase biosynthesis are natural fat ${ }^{\mathbf{1 0}-11}$. The enzymes also act better in emulsion systems ob-tained by mechanical methods or by adding emulsifiers. Lee et al. ${ }^{18}$ reported an over 7 -fold increase of the Bacillus thermolevorans lipase activity with olive oil as a substrate and almost a 10 -fold increase of the activity with the soybean oil, in relation to the lipase activity towards tributyrin as a substrate. The selection of an appropriate the substrate to determine the enzymatic activity, as well as culture conditions, is very important because it enables to distinguish lipases from the related esterases that show a very low activity towards lipids ${ }^{15}$. The reports of many authors ${ }^{15,16-18}$ show that the $\mathrm{Ca}^{2+}$ ions stimulate the lipase activity. The authors explain the positive influence of the $\mathrm{Ca}^{2+}$ ions by their interaction with free fatty acids and, thus, helping to remove the product from the interfacial surface in which the enzyme acts. In our tests, the conditions under which the enzymatic

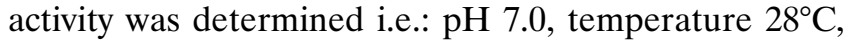
Tween 80 and $\mathrm{CaCl}_{2}$ were identical for all the strains, which might be the reason of some discrepancies in their lipolytic activity, in relation to literature data. When analysing the lipase of Pseudomonas fluorescens, Makhzoum et al. ${ }^{16}$ reported that on the me-dium with tributyrin, it reaches the optimum activity at $40^{\circ} \mathrm{C}$ and $\mathrm{pH} 8.5$. The 
reduction of $\mathrm{pH}$ to 7.0 and the temperature to $30^{\circ} \mathrm{C}$ resulted in an over $55 \%$ decrease of enzyme synthesis, whereas the enrichment of the nutrient medium with $\mathrm{CaCl}_{2}$ increased the enzyme production by $125 \%$. When testing Pseudomonas fragi strain similar in respect of culture requirements, Pabai et al. ${ }^{19}$ observed only a $15 \%$ drop of its lipolytic activity in the nutrient medium at neutral $\mathrm{pH}$. On the other hand, in the studies of Donga et al. ${ }^{20}, \mathrm{pH} 7.0$ was optimal for the lipase of Pseudomonas sp. and the addition of $\mathrm{CaCl}_{2}$ resulted in as much as $150 \%$ increase of the lipase activity.

When analysing the results of the ability of the proteinase synthesis, Bacillus U12 strain had the highest activity that reached $31,40 \mu \mathrm{UA}$. A slightly lower activity (by 6.2 - 7.8\%) was determined for the following strains: Acinetobacter lwoffii (29.45 $\mu \mathrm{UA})$, Bacillus U11 (29.16 $\mu \mathrm{UA})$ and Pseudomonas fluorescens U19 (28.95 $\mu \mathrm{UA})$. The ability of enzyme synthesis by Pseudomonas fluorescens U25 was over $25 \%$ lower and reached 22.62 $\mu \mathrm{UA}$. The proteolytic activity of the remaining strains was over $64 \%$ lower in relation to the most active strain, except for Bacillus U15 and U18 for which the activity reached $16.96 \mu \mathrm{UA}$ and $14.29 \mu \mathrm{UA}$ (Table 1, Fig. 2). The strong ability of Bacillus bacteria for the pro-teinase synthesis is confirmed in reports of many authors ${ }^{2-10,11-21}$. Almost $60 \%$ of the world production of enzymatic preparations includes the proteinases obtained on the basis of the cultures of the bacteria. In our studies, the inducers of the proteinase synthesis were: casein and albumin. According to Trzmiel et al. ${ }^{\mathbf{1 0}}$, the addition of casein or another protein component, e.g. whey, to the medium is a necessary precondition to obtain a high activity of proteinases in the postculture liquid.

Catabolic repression is an important control mechanism of enzyme biosynthesis. The reports of many authors ${ }^{10-11-22}$ show that the efficiency of the proteinase synthesis of some microorganisms is significantly inhibited by the presence of the easily available sources of carbon on the medium e.g. glucose. However, according to Trzmiel ${ }^{11}$, Bacillus strains are not subject to typical catabolic repression and the easily available sources of carbon do not inhibit enzyme production. Moreover, the addition of individual amino acids does not result in repression; only the introduction of their mixture e.g. casein hydrolysate inhibits the proteinase synthesis. Furthermore, ammonium ions are strong repressors of their synthesis. Studies of many authors ${ }^{2}-23$ demonstrate that Pseudomonas fluorescens, Enterobacter sp., Acinetobacter junii, Aeromonas caviae strains behave likewise. In our studies, a large diversity of the activity of proteolytic bacteria within a given genus e.g. Bacillus, Pseudomonas was observed (Fig 2). The applied culture conditions were identical for all strains i.e. the temperature of $28^{\circ} \mathrm{C}$ and $\mathrm{pH}$ 7.0. According to Peterson and Guderson ${ }^{23}$, Pseudomonas fluorescens intensively produces proteolytic enzymes within the range from $25^{\circ} \mathrm{C}$ to $30^{\circ} \mathrm{C}$. On the other hand, the Bacillus subtilis strain was tested by $\operatorname{Trzmie}^{11}$ at $30^{\circ} \mathrm{C}$. According to literature data ${ }^{6-10-11}$, the optimal $\mathrm{pH}$ of the medium for growth of microorganisms does not always coincide with the optimum $\mathrm{pH}$ value for the enzymatic activity. In our studies, the bacterial culture was maintained at $\mathrm{pH} 7.0$, obtaining the number of bacteria reaching $10^{9} \mathrm{CFU} / \mathrm{ml}$. Similar results were obtained

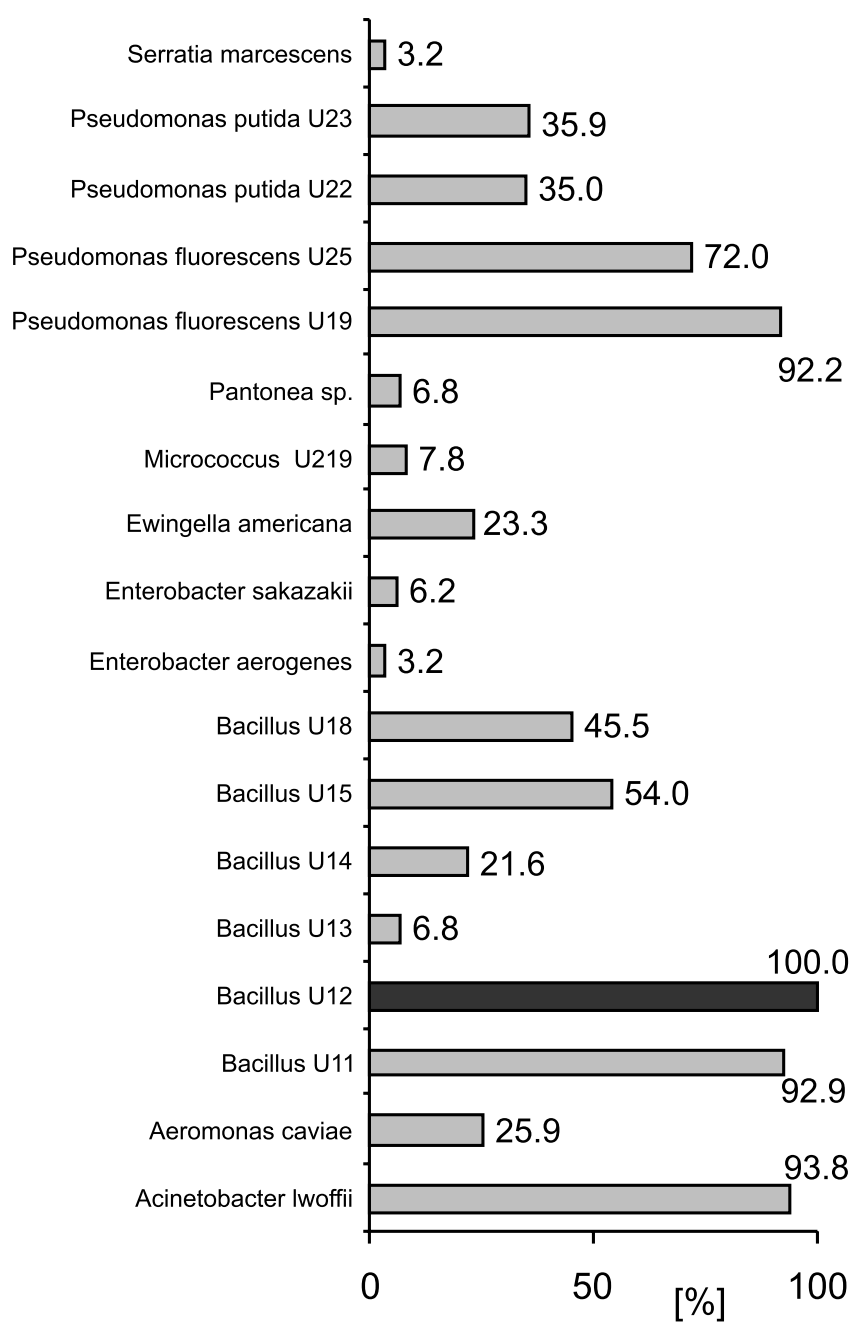

Figure 2. The percentage of the proteolytic activity of Turawa Lake bacteria in relation to the most active strain

by Trzmiel ${ }^{11}$, however, the maximum proteinase synthesis in Bacillus subtilis strain, he reported, occurred at $\mathrm{pH}$ 8.5.

The isolated bacterial strains able to grow on the nutrient medium with powdered cellulose were evaluated for the cellulolytic activity. In total, 6 Bacillus strains, 3 Cellulomonas strains and 2 Cytophaga strains were tested. Despite high lipolytic and proteolytic activity of the Pseudomonas bacteria, no signs of growth on the medium with cellulose were observed for any of the isolated strains.

Table 2. An evaluation of the cellulolytic activity of the selected bacterial strains

\begin{tabular}{|c|c|c|}
\hline \multirow[b]{2}{*}{ The name of the strain } & \multicolumn{2}{|c|}{ Enzymatic activity } \\
\hline & $\begin{array}{c}\text { proteolytic } \\
{[\mu \cup A]^{1}}\end{array}$ & $\begin{array}{c}\text { lipolytic } \\
{[\cup A]^{2}}\end{array}$ \\
\hline Serratia marcescens & 1.00 & 11.00 \\
\hline Pseudomonas putida U23 & 8.22 & 12.00 \\
\hline Pseudomonas putida U22 & 11.28 & 8.50 \\
\hline Pseudomonas fluorescens U25 & 22.62 & 13.00 \\
\hline Pseudomonas fluorescens U19 & 28.95 & 18.00 \\
\hline Pantoea sp. & 2.14 & 10.00 \\
\hline Micrococcus U219 & 2.45 & 3.50 \\
\hline Ewingella americana & 7.32 & 6.00 \\
\hline Enterobacter sakazakii & 1.96 & 12.00 \\
\hline Enterobacter aerogenes & 1.00 & 12.50 \\
\hline Bacillus U18 & 14.29 & 3.50 \\
\hline Bacillus U15 & 16.96 & 3.00 \\
\hline Bacillus U14 & 6.79 & 12.25 \\
\hline Bacillus U13 & 2.14 & 8.00 \\
\hline Bacillus U12 & 31.40 & 2.00 \\
\hline Bacillus U11 & 29.16 & 3.00 \\
\hline Aeromonas caviae & 8.15 & 6.50 \\
\hline Acinetobacter Iwoffii & 29.45 & 12.35 \\
\hline
\end{tabular}


Only few reports ${ }^{13}$ show the ability of cellulolytic activity of Pseudomonas bacteria. The highest cellulolytic activity characterised aerobic gramnegative Cytophaga bacteria. After 2 weeks, the mass decrement of the cellulose disk in the cultures of the strains ranged from $40.8 \%$ to $42.3 \%$. About. 2-times lower activity was observed for Cellulomonas bacteria. For Cellulomonas U3 strain, cellulose reduction reached 22.3\%, for Cellulomonas U1 $21.3 \%$, and for Cellulomonas U2 - 18.3\% after 14 days of culture (Table 2, Fig. 3).

When the synthesis of cellulase and cellobiase is induced, the mesophilic aerobic Cytopahga bacteria decompose cellulose and other polysaccharides (e.g. starch, chitin, agar) to glucose. The sugar can then be degraded to $\mathrm{CO}_{2}$ and $\mathrm{H}_{2} \mathrm{O}$, or be subjected to repolymerisation, forming a mucus capsule around the bacteria. The temperature optimum for the bacteria is within the range of $20-35^{\circ} \mathrm{C}$, and cellulose decomposition is most intensive in neutral environment and is stimulated by presence of $\mathrm{Ca}^{2+}, \mathrm{Mn}^{2+}$, $\mathrm{Fe}^{2+}$ and $\mathrm{Cu}^{2+}$ ions. Janas et al. ${ }^{22-25}$ also confirm the inductive influence of substrate (cellulose) on cellulase biosynthesis. In our tests, the cellulolytic activity of Cellulomonas U1, U2 and U3 bacteria was from $47.3 \%$ to $56.7 \%$ lower than that of the most active strain. Furthermore, Gołębiowska ${ }^{26}$ reports ca. $50-60 \%$ lower activity in cellulose decomposition by Cellulomonas bacteria in 15-20-day cultures, in relation to the Cytophaga activity. The author also shows that the bacteria do not completely mineralise cellulose, but can form by-products like uronic acids or dyes. These bacteria are also less sensitive to environment acidification and show enzymatic activity even at $\mathrm{pH}$ of 4.0. The cel-lulolytic activity of the remaining Bacillus strains was from $68.1 \%$ to $83.9 \%$ lower than that of the most active strain. Cellulose reduction after 14 days ranged from $8.4 \%$ to $12.4 \%$. The ability to produce cellulolytic enzymes by the following Bacillus: Bacillus circulans, Bacillus polymyxa, Bacillus thermoalkaliphilus, is confirmed by the studies of many au-thors ${ }^{13-27-28-29}$. According to Górska and Russel ${ }^{29}$, the tested Bacillus polymyxa strain was able to degrade various cellulose sources, among others, filter paper, crystalline cellulose or CM-cellulose. Moreover, the authors found that in some bacteria the microbiological cellulose decomposition depended on cellulolytic enzymes that are organised in the structures called cellulosomes. According to Begiun ${ }^{27}$, most Bacillus bacteria are able to synthesise endo- $\beta-1,4$-glucanase that hydroly-ses 1-4-glycoside bonds inside amorphous regions of cellulose. Thus, the production of this group of cellulases is associated with the decomposition of watersoluble cellulose derivatives such as CM-cellulose. The decom-position of natural cellulose, in which the fibres outside the amorphous regions also contain crystalline regions, is catalysed by exo- $\beta-1,4-$ glucanase and then by cellobiose. The lack of ability to produce exo- $\beta-1,4$-glucanase and cellobiase limits the involvement of Bacillus bacterial in cellulose mineralisation. In our studies, the cellulolytic activity of Bacillus bacteria could also result from the protease biosynthesis by the strains. When analysing the enzymatic activity of Trichoderma reesei, Janas et al. ${ }^{22}$ observed $58 \%$ to $76 \%$ reduction of the cellulase activity, after the incubation of the post-culture liquids of fungi with the highest proteolytic and cellulolytic activity, depending on the strain, the

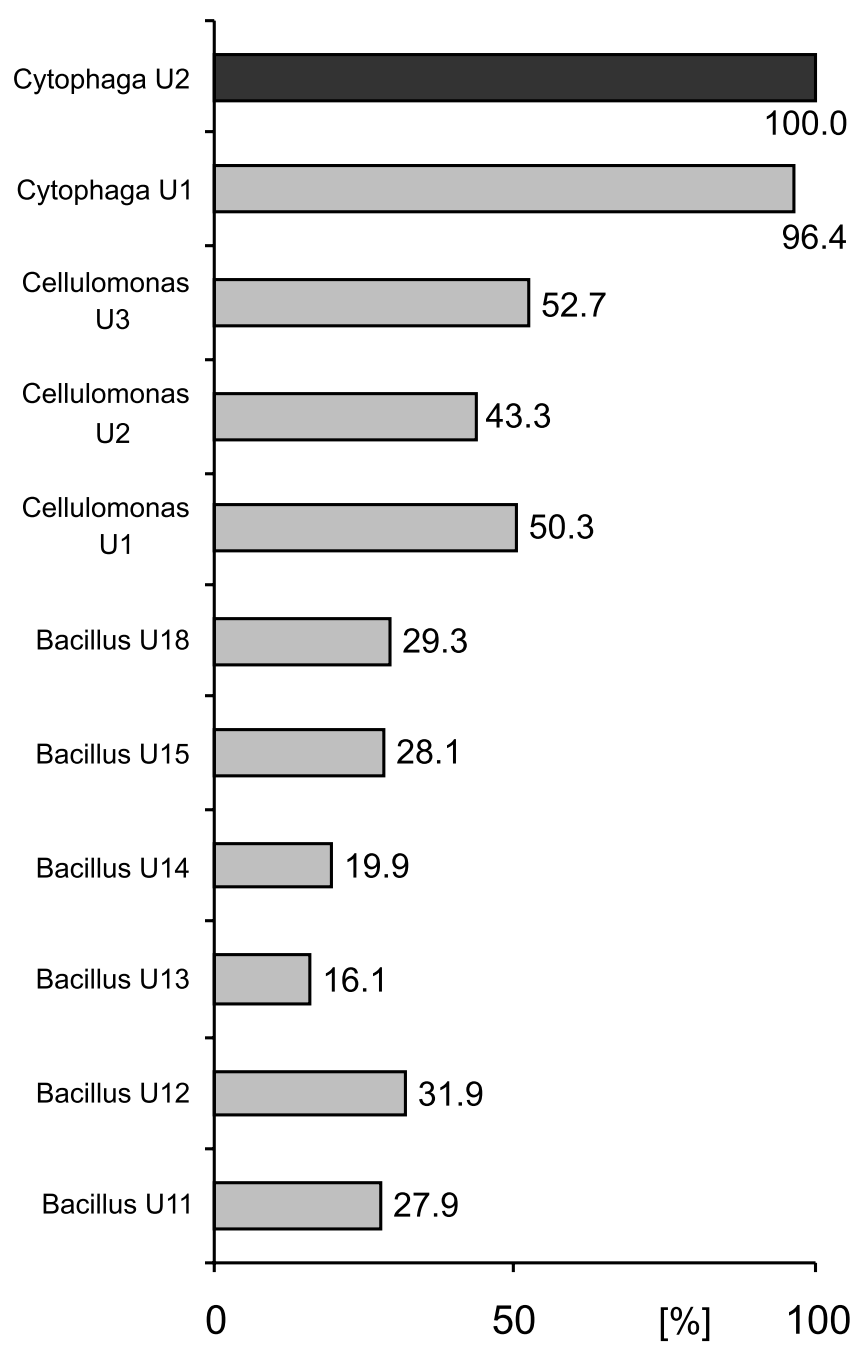

Figure 3. Percentage of cellulolytic activity of Turawa Lake bacteria in relation to the most active strain

volume of the post-culture filtrates and the time of incubation.

\section{CONCLUSIONS}

In this work we attempted to evaluate the enzymatic activity of 24 bacterial strains isolated from the water and the bottom sediments of Turawa Lake. Pseudomonas and Bacillus strains proved to be most active in the synthesis of the lipolytic and proteolytic enzymes in our experimental conditions. Pseudomonas fluorescens U19 strain displayed the highest ability of lipase synthesis reaching the enzyme activity of 18.00 UA. The highest proteolytic activity, $31.40 \mu \mathrm{UA}$, was observed for Bacillus U12 strain. At the lowest end of the lipase and protease activity scales was Micrococcus U219 strain. In cellulose decomposition, Cytophaga and Cellulomonas were dominating strains, but only small activity was observed for Bacillus. The cellulolytic activity of aerobic Cytophaga bacteria was about 2-times higher than that of Cellulomonas bacteria. The degradation of cellulose after 14 days of culture was $40.8-42.3 \%, 18.3-22.3 \%$ and $16.1-31.9 \%$ for Cytophaga, Cellulomonas and Bacillus strains, respectively. The enzymatic activity of microorganisms highly depends on culture conditions. However, the optimal conditions for microorganism growth are not always the most favourable for achieving the maximum activity of the enzymes produced. All of the enzymes studied here can be consid- 
ered as inductive enzymes. An addition of an appropriate substrate to the medium increases their production several times.

\section{LITERATURE CITED}

(1) Leśniak W.: Biotechnologia żywności. Procesy fermentacji i biosyntezy, Wydawnictwo Akademii Ekonomicznej im. O. Langego, Wrocław, 2002.

(2) Gajewski A.: Znaczenie ektoenzymów produko-wanych przez mikroorganizmy w procesach przekształceń i degradacji biopolimerów organicznych w ekosystemach wodnych, Postępy Mikrobiologii, 1994, 4, 513 - 542.

(3) Latała A., Wierzba S., Latała B.: Biological utili-sation of fatty waste - initial laboratory examination, Biotechnologia, 2000, 1(48), $124-134$.

(4) Latała A., Wierzba S.: Ocena aktywności biodegradacyjnej wybranych szczepów bakterii lipolitycznych, Biotechnologia, 2004, 3(66), 193 - 201.

(5) Burbianka M., Pliszka A., Murzyńska H.: Mikrobiologia żywności. Państwowy Zakład Wydawnictw Lekarskich Warszawa. 1983.

(6) Latała A., Wierzba S., Farbiszewska T., Polaczek B., Boniewska E.: Biodegradacja odpadów gospodarczych przy użyciu szczepów bakterii lipolitycznych, proteolitycznych i celulolitycznych, Biotechnologia, 2004, 3(66), 202 - 213.

(7) PN-75/C-04615, Badania mikrobiologiczne. Oznaczanie ogólnej liczby bakterii metodą płytkową.

(8) Holt J. G., Krieg N. R.: Bergey's manual of systematic bacteriology. Williams\&Wilkins. Baltimore, 1984.

(9) Ionita A., Moscovici M., Popa C., Vamanu A., Popa O., Dinu L.: Screening of yeast and fungal strains for lipolytic potential and determination of some biochemical properties of microbial lipases. Journal of Molecular Catalysis B: Enzymatic, 1997, 3, 147 - 151 .

(10) Trzmiel T., Szczęsna M., Galas E., Regulacja bio-syntezy niektórych pozakomórkowych enzymów u Bacillus subtilis IBTC-3. Wpływ składu podło-ża hodowlanego. Biotechnologia, 1994, 1 (24), 148-156.

(11) Trzmiel T.: Wpływ pH i temperatury hodowli na biosyntezę niektórych pozakomórkowych enzymów u Bacillus subtilis IBTC-3, Biotechnologia, 1994, 2 (25), 21 - 31.

(12) Trojanowski J.: Przemiany substancji organicznych w glebie. PWRiL, Warszawa, 1973.

(13) Bujak S., Targoński Z.: Mikrobiologiczna degra-dacja materiałów ligninocelulozowych, Postępy mikrobiologii, 1988, 27 (3), $211-241$.

(14) Antczak T., Graczyk J.: Lipazy: źródła, struktura i właściwości katalityczne. Biotechnologia, 2002, 2 (57), 130 145.

(15) Adamczak M., Bednarski W.: Lipazy - narzędzie w biotechnologii tłuszczów i olejów. Biotechnologia, 1994, 4 (27), $140-153$.

(16) Makhzoum A., Owusu R. K., Knapp J. S.: The conformational stability of lipase from Pseudomonas fluorescens 2D. Food Chem., 1993, 46, 355 - 359.

(17) Pilarek M., Szewczyk K. W., Wrona M.: Kierunki i perspektywy zastosowania lipaz. Biotechnologia, 2002, 2 (57), $146-164$.

(18) Lee D.-W., Koh Y.-S., Kim K.-J., Kim B.-C., Choi H.J., Kim D.-S., Suhartono M. T., Pyun Y.-R.: Isolation and characterization of a thermophilic lipase from Bacillus thermoleovorans ID-1. FEMS Microbiology Letters, 1999, $179,393-400$

(19) Pabai F., Kermasha S., Morin A.: Lipase from Pseudomonas fragi CRDA 323: Patrial purification, charakterization and interesterification of butter fat. Appl. Microbiol. Biotechnol., 1995, 43, 42 - 51.
(20) Dong H., Gao S., Han S.-P., Cao S.-G.: Purification and characterization of a Pseudomonas sp. lipase and its properties in nonaqueous media. Biotechnol. Appl. Biochem., 1999, 30, 251 - 256.

(21) Szwed A., Gostkowska K.: Próba kompostowania odpadów tytoniowych. Cz. II. Ocena niektórych uzdolnień biochemicznych drobnoustrojów akty-wizujących proces kompostowania odpadów ty-toniowych. ZPPNR, 1996, 437, $329-335$.

(22) Janas P., Podgórska E., Mleko S., Pielecki J.: Biosynteza enzymów proteolitycznych i ich wpływ na aktywność celulaz Trichoderma reesei, Annales UMCS, Sec. E, 2004, 59 (1), $461-469$.

(23) Peterson A. C., Gunderson M. F.: Some characteristic of proteolytic enzymes from Pseudomonas fluorescens, Applied microbiology, 1990, 150 (4), 98 - 104.

(24) Liebert C. A., Hood M. A., Deck F. H., Bishop K., Flaherty D. K.: Isolation and characterization of a new Cytophaga species implicated in a workrelated lung disease, Applied and Environmental Microbiology, 1984, 48 (5), 936 $-943$.

(25) Janas P., Targoński Z., Mleko S.: Wpływ wybranych monosacharydów na biosyntezę celulaz, ksylanaz i enzymów litycznych przez mutanta Trichoderma reesei M-7, Biotechnologia, 2002, 1 (56), 195 - 207.

(26) Gołębiowska J.: Mikrobiologia rolnicza, PWRiL, Warszawa, 1992.

(27) Beguin P., Aubert J. P.: The biological degradation of celulose, FEMS Microb. Rev., 1994, 13, 1, 25 - 58.

(28) Górska E., Omar El-Haj K., Russel S.: Charakterystyka czterech celulolitycznych szczepów bakterii z rodzaju Bacillus wyizolowanych z gleby, Zezyty problemowe Postępu Nauk Rolniczych, 1997, 439, 91 - 96.

(29) Górska E., Russel S.: Charakterystyka wyizolo-wanego z gleby szczepu Bacillus polymyxa, Drobnoustroje w środowisku - występowanie, aktywność i znaczenie, Wydział Rolniczy AR. Kraków, 1997, 159 - 167. 